\title{
Trade Fair and B\&R Initiative-Based Market Exploring: A Perspective of Kazakhstan
}

\author{
Xuehui Zeng ${ }^{1, a}$, Zhaoyue Xia $^{2, b}$ \\ ${ }^{1}$ Department of Event Management, Shanghai Polytechnic University, Shanghai, 201209, China \\ ${ }^{2}$ Department of Event Management, Shanghai Polytechnic University, Shanghai, 201209, China \\ aemail: xhzeng@sspu.edu.cn, bemail: xiazhaoyue@163.com
}

Keywords: B\&R Initiative; Market Exploring; Trade Fair; Kazakhstan

\begin{abstract}
Under “the Silk Road Economic Belt and the 21st-Century Maritime Silk Road”(B\&R) initiative, this paper analyses Kazakhstan's industry structure, import-export commodities from and to China through categories and HHI index. Studies indicate that Kazakhstan has comparative advantageous industries such as oil and gas, mineral resources exploitation and primary processing, wheat and cotton production, etc. Kazakhstan's competitive disadvantageous industries are transportation infrastructure, power infrastructure and manufacturing. Industries between China and Kazakhstan are highly complementary, so the two countries have foundation and conditions for industrial cooperation. Trade fair functions and how it works as the marketing tool and the platform to help the Chinese enterprise explore the emerging market is also discussed in the paper.
\end{abstract}

\section{Introduction}

Jointly building the Silk Road Economic Belt and the 21st-century Maritime Silk Road is to promote regional economic cooperation, strengthen cultural exchanges, promote world peace and development, and benefit the world. There are three main features of "the Belt and Road", namely comprehensive effect, project first and domestic development linkage.[3] Under B\&R initiative, trade fair has been given the responsibilities to promote cross-regional cross-border cross-continental policy integration facilities interconnection economic cooperation and cultural communication .

Kazakhstan is China's important neighboring country, located in the core area of "the Silk Road Economic Belt”, which is capable of playing an important role in jointly building "the Silk Road Economic Belt”. Furthermore, China is an important priority nation in Kazakhstan's foreign policy and its important cooperative partner.[1] An analysis of Kazakhstan's new economy policy of "Bright Avenue" and relevant development strategies indicates that there is a great consensus between China and Kazakhstan on their respective foreign policies, development goals and implementation strategies, so that a comprehensive cooperation can be carried out to realize a mutually beneficial win-win success.

\section{Industry Structure of Kazakhstan}

Kazakhstan is a Late-development industrial country, the third industry share of GDP is higher than that of the second industry, but the total volume of GDP is much less than the numerous coastal countries.

Kazakhstan's first industry in GDP is low, but the types of agricultural and sideline products has distinguishing feature. Unfortunately, however, Kazakhstan's exports of agricultural and sideline products are mainly low value-added, In the process of international trade, food processing industry holds an important place. Yet, Kazakhstan has no large-scale food processing equipment, so complete sets of mechanical manufacturing and electronic machinery need to be imported. Kazakhstan main imports to China's are plastic, rubber, textiles and raw materials such as primary manufactured goods.[2] So the rubber plastic manufacturing and textiles industrial enterprise has the opportunity to enter into the market of Kazakhstan.[1] Kazakhstan's Industry Structure and its 
Share of GDP is shown in Table 1.

Table 1 Kazakhstan's Industry Structure and its Share of GDP

\begin{tabular}{|l|l|l|l|l|l|l|}
\hline Year & $\begin{array}{l}\text { Primary } \\
\text { Industry } \\
\text { Output } \\
\text { Value }\end{array}$ & $\begin{array}{l}\text { Share of } \\
\text { GDP }\end{array}$ & $\begin{array}{l}\text { Secondary Industry } \\
\text { Output Value }\end{array}$ & $\begin{array}{l}\text { Share of } \\
\text { GDP }\end{array}$ & $\begin{array}{l}\text { Tertiary } \\
\text { Industry } \\
\text { Output } \\
\text { Value }\end{array}$ & $\begin{array}{l}\text { Share of } \\
\text { GDP }\end{array}$ \\
\hline 2010 & 97.8 & 6.7 & 797.90 & 54.3 & 871 & 39.0 \\
\hline 2011 & 154.0 & 8.3 & 1068.0 & 57.4 & 640.00 & 34.3 \\
\hline 2012 & 150.91 & 7.5 & 1114.50 & 55.3 & 751.19 & 37.2 \\
\hline 2013 & 160.00 & 7.3 & 1196.30 & 54.3 & 846.70 & 38.4 \\
\hline 2014 & 135.60 & 5.9 & 999.30 & 43.5 & 1162.80 & 50.6 \\
\hline
\end{tabular}

Source: Ministry of Commerce of the People’s Republic of China

\section{Top Exports and Imports of Kazakhstan}

According to the report from Ministry of Commerce of the People's Republic of China , Kazakhstan is the 48th largest export economy in the world and the 52nd most complex economy according to the Economic Complexity Index (ECI). In 2014, Kazakhstan exported \$68.3B and imported \$42.2B, resulting in a positive trade balance of \$26.1B. In 2014 the GDP of Kazakhstan was $\$ 217 \mathrm{~B}$ and its GDP per capita was $\$ 24.2 \mathrm{k}$. The top exports of Kazakhstan are Crude Petroleum (\$39.7B),Refined Petroleum (\$3.6B), Petroleum Gas (\$3.51B), Radioactive Chemicals (\$2.26B) and Refined Copper (\$1.99B), using the 1992 revision of the HS (Harmonized System) classification. Its top imports are Cars (\$2.32B), Refined Petroleum (\$1.49B), Packaged Medicaments (\$1.1B), Planes, Helicopters, and/or Spacecraft $(\$ 842 \mathrm{M})$ and Computers(\$682M).[7] Kazakhstan's five categories of export and import Commodities to and from China between January to June,2016 is shown in Table 2 and Table 3. HHI Index of the Major Export \&export Commodity in Kazakhstan is shown in Fig.1 and Fig.2.

Table 2 Kazakhstan's Five Categories of Export Commodities to China between January to June,2016

\begin{tabular}{|l|c|c|}
\hline \multicolumn{1}{|c|}{ Category } & Sum Million Dollar & Percentage \% \\
\hline HS25-27: mineral & 652 & 6.4 \\
\hline HS72-83: Base metal and product & 818 & 33.6 \\
\hline HS28-38: chemical product & 486 & 48.7 \\
\hline HS06-14: plant product & 55 & 7.9 \\
\hline HS71: precious metal and product & 1 & 0.3 \\
\hline
\end{tabular}

Source: Ministry of Commerce of the People's Republic of China

Table 3 Kazakhstan's Five Categories of Import Commodities from China between January to June,2016

\begin{tabular}{|c|c|c|}
\hline Category & Sum(million Dollar) & Percentage \% \\
\hline HS84-85: mechanical and electrical product & 695 & 28.6 \\
\hline HS72-83: Base metal and product & 219 & 20 \\
\hline HS28-38: chemical product & 90 & 10.8 \\
\hline HS86-89: transportation equipment & 70 & 14.6 \\
\hline HS06-14: plant product & 39 & 9.8 \\
\hline
\end{tabular}

Source: Ministry of Commerce of the People’s Republic of China 


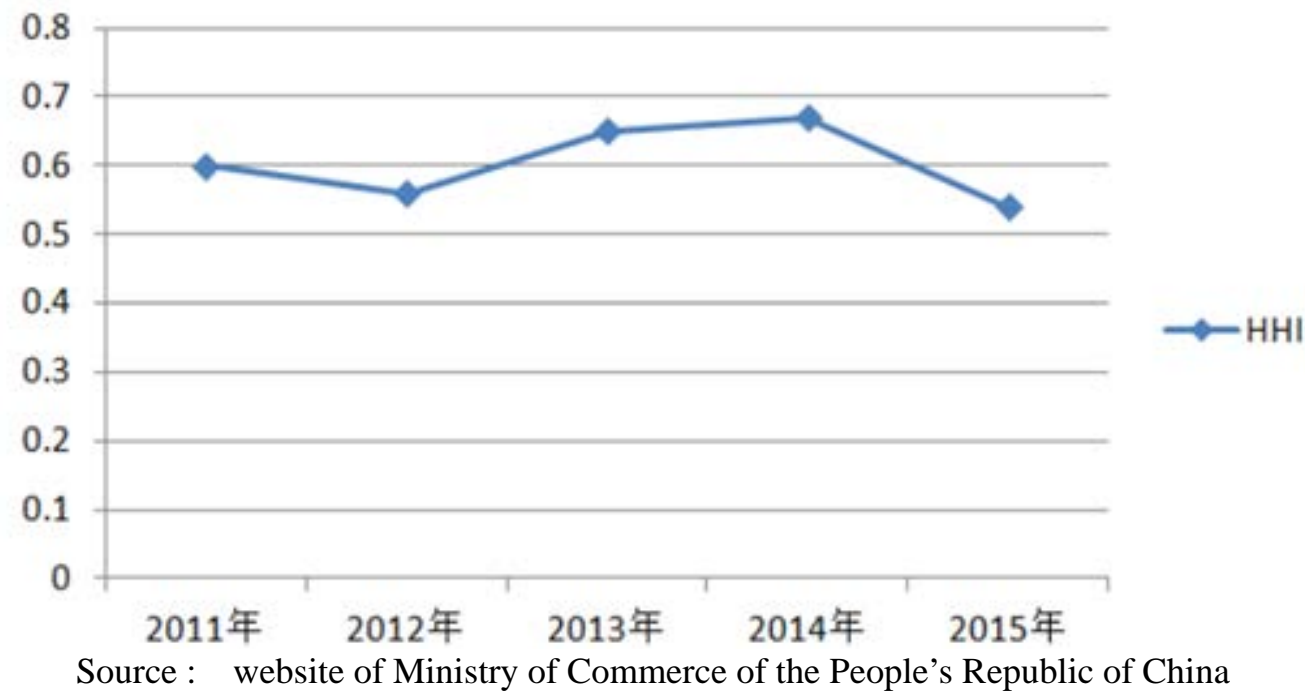

Fig.1 HHI Index of the Major Export Commodity in Kazakhstan

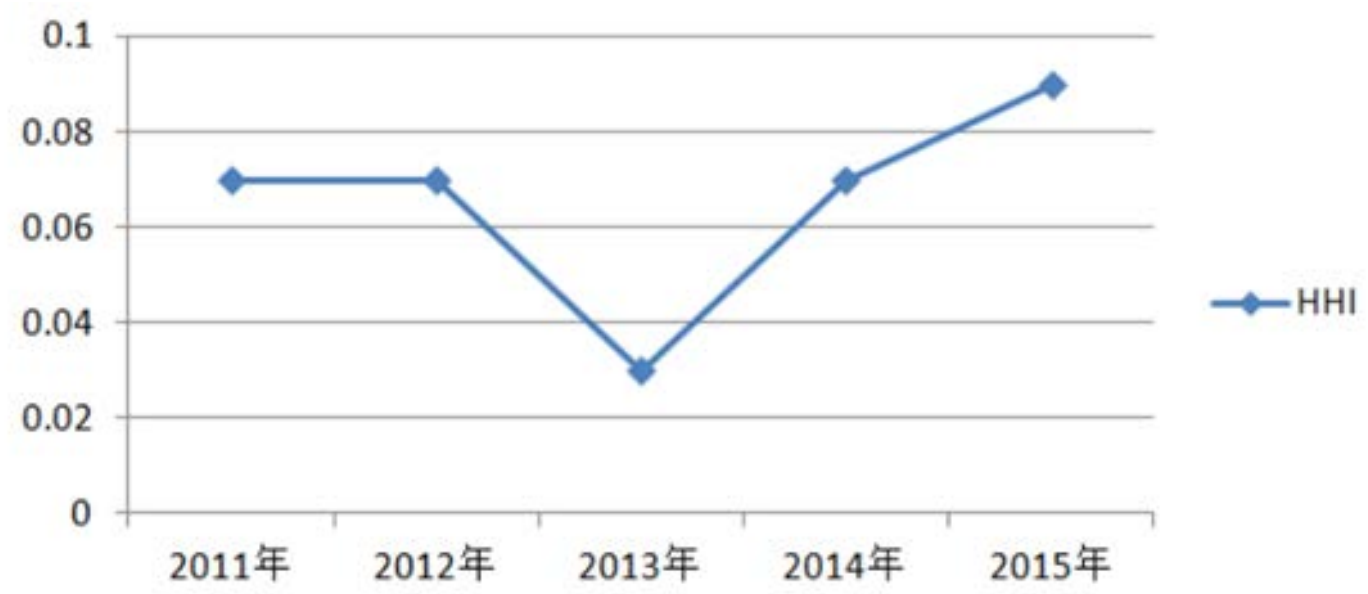

Source : website of Ministry of Commerce of the People's Republic of China

Fig.2 HHI Index of the Major Import Commodity in Kazakhstan

\section{Discussion}

The basic functions of every fair or exhibition is to join supply and demand, provide information, and show technical trends and developments, all in one time and in one place, using face-to-face communication. Fairs and exhibitions are a unique opportunity for achieving trade objectives, because they are the most efficient way to reach a complete market audience and do business all in one shot. Fairs and exhibitions are also an indicator of economic and market trends, because they reflect market procedures, types and scopes of market changes, as well as directions and speed of future developments. Fairs \& exhibitions are more than just a marketing tool, they are an entire market place. The function of fairs to serve as a place for personal contacts and face-to-face communication will remain of fundamental importance in the times of increasing use of telecommunication means, new media, and Internet.[4]

Recognition the function of trade fair. Trade fair is the marking tool and platform to connect the demand and supply. The exhibition is a platform of cooperation and communication. In the process of organizing the trade fair, the organizers can take the industry chains together. Exhibitors can not only promote their products and services, but also can find a large number of upstream and downstream enterprises, make trade partner by attending the trade fair. At the same time, the concurrent events like forums and seminars provide more net working opportunities for professionals, scholars and practitioners to exchange opinions.[5]

Recognition of the importance of infrastructure facilities. Venues are the fundamental for the 
domestic and international trade fair. Atakent Exhibition Centre in Kazakhstan was founded in 1992, 40-50 large-scale international exhibition can be held every year and receive the recognition and favor of the large well-known enterprises from home and abroad The exhibition center is located in the capital of Kazakhstan and it is Kazakhstan's largest exhibition hall, there are more than five exhibition hall and several conference rooms in line with the international standard, a total exhibition area is 12,800 square meters.[6] The Exhibition center held the most influential exhibitions include: Kazakhstan national building exhibition(spring and autumn), oil and gas shows, food industry fair, mining fair, Kazakhstan international logistics fair, furniture and interior decoration and design exhibition, etc. Trade fair and facilities in Kazakhstan is shown in Table 4.

Table 4 Trade fair and facilities in Kazakhstan

\begin{tabular}{|l|l|l|l|}
\hline \multicolumn{1}{|c|}{ Name of the Trade Fair } & \multicolumn{1}{|c|}{ Venue } & Frequency & Type \\
\hline $\begin{array}{l}\text { Clothing, Fashion Accessories and } \\
\text { Footwear Fair }\end{array}$ & Atakent Exhibition Centre & Once a year & B to C show \\
\hline $\begin{array}{l}\text { International Engineering } \\
\text { Construction Exhibition in Almaty }\end{array}$ & Atakent Exhibition Centre & Once a year & Trade fair \\
\hline $\begin{array}{l}\text { Astana International Agriculture } \\
\text { and Animal Husbandry Exhibition }\end{array}$ & Atakent Exhibition Centre & Once a year & Trade fair \\
\hline HOMELIFE & Atakent Exhibition Centre & Once a year & B to B show \\
\hline
\end{tabular}

Source: China's Ambassador to the Office of Commercial Counselor of Kazakhstan

Marketing and attracting the exhibitors to attend the trade fair are the vital factors to the success of economic cooperation. Attract and organize the Chinese enterprises to take part in the outbound exhibition in Kazakhstan and display their products and service in the modern processing industry like cotton textile , agricultural. Attract the enterprise of Kazakhstan in attend the trade fair held in China in the field of mineral , base metal , chemical product ,plant product and precious metal.[5]

\section{Conclusion}

“The Belt and Road” initiative is a strategy launched by Chinese government for opening up in the new era, which focuses on the communication in policy, infrastructure, trade, capital and person in the region. China should treasure the opportunity to participate in the communication and cooperation promoted by "the Belt and Road" initiative and try to make win-win deals for all partners. Trade fairs are market events of a specific duration, held at intervals, at which a large number of companies present the main product range of one or more industry sectors and mainly sell it on the basis of samples. Trade Fairs predominantly attract trade and business visitors. As part of the marketing-mix, the participation in a fair/exhibition is by far the most valuable tool. Considering the presentation of the full product/service range of a company, combined with the personal contacts with the clients and prospects, no other marketing instrument is more efficient than a trade fair participation.

\section{Acknowledgement}

This research was supported by the Tourism Management Discipline Research Program funded by Shanghai Polytechnic University, P.R. China (Grant NO. XXKPY1607).

\section{References}

[1] Kazakhstan at a glance, Kyrgyz Republic at a glance, Tajikistan at a glance, Turkmenistan at a glance, Uzbekistan at a glance [EB/OL]. World Bank, http://data.worldbank.org/data-catalog (2012-12-22).

[2] Statistical Yearbook Kazakhstan in 2011 [M] Agency on Statistics of the Republic of Kazakhstan, 2012. 
[3] Qiao Mu. One Belt And One Road Strategic Structure Model Analysis [J]. Management Survey 17, 2015

[4] Huang Ying, Luo Chuanyu \& Huang Qin, Interactive Analysis of Brunei Economic and Social Development and “the Belt and Road” Building Around Southeast Asia 2015•11

[5] Yuxiang Liu. Development Study on the Interactive of B\&R Initiative and Exhibition Industry Journal of Henan Business College Vol. 28 No 6 Dec. 2015

[6] China Industrial Statistics Yearbook 2015, The National Bureau of Statistics

[7] Foreign Country (Region) Investment Cooperation Guide 2015, The Ministry of Commerce 